\title{
Role of Indian Railways in Promotion of Tourism in India: A Case Study of Foreign Tourists
}

\author{
Vinod Kumar* Dr. J. B. Komaraiah** \\ * Ph. D. Research Scholar, Department of Economics, Banaras Hindu University, Varanasi -5 \\ **Associate Professor, Department of Economics, Banaras Hindu University, Varanasi - 5
}

\begin{abstract}
Travel has been one of the fastest and ever growing service industries with an enormous potential for further growth in world. The bulk of tourist arrivals are in developed countries but now developing countries are also increasingly sharing in the tourism boom. Tourism has come to play an important role in the socioeconomic development of a country. It is both cause and consequence of economic development. Travel today, is sold like any normal consumer product through retail outlets, wholesalers and even departmental stores of many countries. The reasons for travel too have changed over the span of time. Tourism in India is witnessing widespread growth on the back of increasing inbound tourists by the burgeoning Indian middle class, rising inflow of foreign tourists and successful government campaigns for promoting 'Incredible India'It is a fact that tourism is an inter-disciplinary subject by nature and each of its aspect is too complex and complicated. Form the Indian railway's point of view, the significance of the study lies in identifying and highlighting the problem areas in the field of tourism development. It specially aims towards finding answers to problems and shortcomings in the field of infrastructure development, improvement in quantity and quality of basic amenities for foreign tourists and requirement marketing of and publicity for the promotion of tourism.
\end{abstract}

\section{Introduction:}

Travel has been one of the fastest and ever growing service industries with an enormous potential for further growth in world. The bulk of tourist arrivals are in developed countries but now developing countries are also increasingly sharing in the tourism boom. Tourism has come to play an important role in the socio-economic development of a country. It is both cause and consequence of economic development. Travel today, is sold like any normal consumer product through retail outlets, wholesalers and even departmental stores of many countries. The reasons for travel too have changed over the span of time. Tourism in India is witnessing widespread growth on the back of increasing inbound tourists by the burgeoning Indian middle class, rising inflow of foreign tourists and successful government campaigns for promoting 'Incredible India'. Infrastructure development holds the key to India's sustained growth in the Tourism sector. The tourism industry is primarily related to the service and people oriented; it is made up of businesses and organizations belonging to various other industries and sectors. It is the interplay among these businesses and organizations/persons which offers "travel experience" to tourists. The tourism industry comprises hospitality (related to accommodation and dining), travel (transportation services through different modes), and various other businesses which offer services and products to tourists.

Indian Railways and Tourism: The tourism in India cannot be possible without the train journey since it is a commonly used mode of public transportation in the country. Trains are not only cheaper and reliable mode of transport in India but also touch almost all important and less important places of tourism. They encourage tourism by offering different promotional schemes, tour packages, special trains, charter trains, luxurious trains, coaches to tourist domestic as well as foreign.

Concept of the promotion: Promotion is one of the market mix elements or features, and a term used frequently in marketing. A promotional plan can have a wide range of objectives, including: sales increases, new product acceptance, creation of brand equity, positioning, competitive retaliations, or creation of a corporate image.

However, fundamentally there are three basic objectives of promotion:

$>$ To present information to consumers as well as others.

$>$ To increase demand of a product or service.

$>$ To differentiate a product or a service from others.

In the context of present study, we have restricted the promotion to the first two objectives as above mentioned. So, for the present study, promotion will mean all the measures which result in increase of the 
volume and frequency of journey on Indian Railways. It will also include those initiatives which lead to enhanced awareness among foreign tourists on different aspects related to services or facilities of Indian Railways. The literature regards customer satisfaction as the basis of promotional activities. Higher tourist's satisfaction is likely to contribute to enhanced reputation of tourism product providers and of the whole destination, increased consumer loyalty; reduced price elasticity lowers cost of future transactions and improved productivity (Anderson et. al., 1994). Studies have revealed that customer satisfaction is likely to produce positive behavioural intentions from customers such as positive word-of-mouth and repeat purchases (Saleh and Ryan, 1992; Barsky, 1992; Bojonic and Rosen, 1994; Kozak and Rimmington, 2000; Gursoy et. al., 2003; Karatepe, 2006; Neal and Gursoy, 2008). So, on the basis of the findings of the above mentioned studies, we can now redefine the promotion for the present study as all those services or measures of Indian railways which ultimately lead to enhancement of satisfaction level or awareness of foreign tourists towards these services or measures.

\section{Review of Literature:}

Research on tourism is considered as an established area of research which has received adorable attention from the researchers. Several authors have reported works on different aspects of tourism research. In the present study, for the sake of simplicity we have divided the reviews into four sub-sections; i.e. reviews related to (1) Developments in Tourism Research (2) Marketing aspect of Tourism Research (3) inter-relationship of Tourism \& Transportation and (4) Tourist Satisfaction-Concept and Measurement.

The tourism industry has evolved into a broad sector comprising many subsectors. In last few years, researches related to the development of tourism have focused on areas like adventure tourism (Weber, 2001; cruise tourism (Kwortnik, 2008), eco-tourism (Stoneman et al., 1995), event tourism (Getz, 2008), medical tourism (Connell, 2006; Michelle, 2009), sex tourism (Oppermann, 1999), special interest tourism (Trauer, 2006), volunteer tourism (Sin, 2009), wedding tourism (Johnston, 2006), and rural tourism etc.

Tourism marketing has been considered vital in the changing competitive marketing environment and there has been a phenomenal rise in the academic research activities on the marketing aspects of tourism. Chaudhary (2000) has reported its importance with the help of domain specific data and relevant analysis. Theoretical analysis involving different issues in formulating strategies for destination marketing was outlined by Buhalis (2000), Wheeler (1995) observed that ethical marketing of tourism products advocates promotion of destination to attract larger number of tourists while tourism industry was analysed in a holistic manner through distribution channel perspectives by various authors (Laws, 1997; Halloway, 1998; Middleton and Clark, 2001; Mill and Morrison, 2002). Very few researches were focusing on the role of transportation in promotion of tourism have been conducted till now. In one of such researches, Page and Lumsdon (2004) argue that the transportation system of a tourist destination has an impact on the tourism experience which explains how people travel and why they choose different forms of holidays, destination, and transport etc. Tourist's satisfaction is an emotional state after experiencing the trip (Baker and Crompton, 2000). When experiences compared to expectations result in feelings of gratification, the tourist is satisfied. However, when they result in feelings of displeasure, the tourist is dissatisfied (Reisinger \& Turner, 2003). According to Kozak and Rimmimgton (2000), satisfaction is on important to successful destination marketing; Philip and Hezlett (1996) also acknowledged that an increasing concentration of customer satisfaction is one of the strategic routes used by leisure firms in gaining competitive edge.

It is a fact that tourism is an inter-disciplinary subject by nature and each of its aspect is too complex and complicated. Form the Indian railway's point of view, the significance of the study lies in identifying and highlighting the problem areas in the field of tourism development. It specially aims towards finding answers to problems and shortcomings in the field of infrastructure development, improvement in quantity and quality of basic amenities for foreign tourists and requirement marketing of and publicity for the promotion of tourism. At this juncture it is important to know how far Indian railways have been successful in her efforts. So, the present study particularly focussing on the following objectives.

\section{Objectives:}

(1) To study socio-economic status of foreign tourists travelling on Indian Railways;

(2) To examine the role of Indian Railways in promoting foreign tourism and

(3) To analyse the problems faced by foreign tourists travelling on Indian Railways.

\section{Research Questions:}

1. What is the socio- economic status of foreign tourists ravelling on Indian Railways?

2. How much Indian railways are satisfying the foreign tourists through its promotional measures?

3. What are the problems faced by foreign tourists while travelling on Indian Railways? 


\section{Methodology:}

For the present study, Luckow division in Northern Railways of Indian railways was selected as a study area purposively. The sample size of 250 respondents was selected for the present study. 50 respondents each were selected from tourist areas by covering 5 trains in which majority of foreign tourists travel. Present study adopts suitably non-probability sampling method particularly, convenience sampling method. Both the primary and secondary are used in the present study. The primary data was collected from 250 tourists respondents in 5 trains namely Marudhar express, Bundel khand Express, Patna Mathura Express, Shiv Ganga Express and Kamayani Express was conducted during August and September 2012. Since the tourists were from diverse backgrounds, the information was collected from only those tourists who had the knowledge of English by considering it Lingua franca.

Data Analysis: The collected data was checked and edited for completeness and accuracy. For the purpose of analysis, we have divided all the result into five subcategories and analyzed them in the following manner:

1. Analysis of present travelling experience over travelling past experiences: Since Indian railways is constantly upgrading itself in terms of infrastructure and provision of facilities, the initiatives taken to enhance present travelling experience over that in past, which ultimately lead to enhancement of satisfaction level of foreign tourists, have been considered as promotion. We have studied it by comparing past travelling experience with the present one.

2. Analysis of travelling behaviour/patterns of tourists: The study considers the knowledge about travelling behaviour of tourists as promotion since this will help Indian railways to frame customer oriented policies which will lead to enhanced satisfaction level of tourists. In order to understand travelling behaviour/ patterns of tourists, we have examined travelling details of the tourists.

3. Analysis of Awareness regarding facilities of Indian Railways among foreign tourists and utilisation of these facilities by them: Since an improvement in the awareness about a product or service, we have considered the efforts of Indian railways to spread awareness about its facilities as promotional measures. So, in order to reflect the success of these promotional measures, we have examined the awareness of foreign tourists about the facilities of Indian Railways and found out whether they are using these facilities.

4. Analysis of satisfaction level of foreign tourists with the facilities provided by Indian railways in general and special for them: Since the facilities provided by Indian Railways aim at the customer's satisfaction; the study considers these facilities as promotional measures. We have tried to measure the satisfaction level of foreign tourists on these facilities so that in case of dissatisfaction, the necessary steps may be taken by Indian Railways (IR) for the further improvement.

5. Analysis of Awareness regarding Rail Tour Packages provided by Indian Railway Catering and Tourism Corporation (IRCTC) among foreign tourists and utilisation of the same by them: Improvement in awareness among foreign tourists regarding Rail tour packages of IRCTC is a promotional agency. Increased awareness about the facilities among those who were earlier unaware about them will improve the chances of using this facility. So, we have examined the awareness of foreign tourists about Rail Tour Packages of IRCTC and the level of satisfaction of those who have used these packages so that necessary steps may be taken in case of dissatisfaction of tourists with these packages.

Analysis of the main findings: Analysis of final data \& its interpretation was done in order to highlight the main findings of the study. Objective wise analysis of few important tables and its interpretation has been presented in this section.

Table -1: Experience of availed services of Indian Railways in earlier visit to India

\begin{tabular}{|l|l|l|}
\hline Overall satisfaction Level & No. of Respondents & Percentage \\
\hline Very Poor & 5 & 5.8 \\
\hline Poor & 9 & 10.5 \\
\hline Average & 24 & 27.9 \\
\hline Good & 45 & 52.3 \\
\hline Excellent & 3 & 3.5 \\
\hline Total & $\mathbf{8 6}$ & $\mathbf{1 0 0 . 0}$ \\
\hline
\end{tabular}

Source: - Field Survey

Table-1 reveals the distribution of respondents by their experience of services of Indian Railways availed in during their earlier visit(s).The table reveals that out of total 86 such respondents, $52.3 \%$ respondents had good experience of services availed. Out of these $52.3 \%$ respondents, $3.5 \%$ had found it excellent. In case of poor experience, $10.5 \%$ respondents had poor experience and $5.8 \%$ had very poor experience of the services provided by Indian Railways. 
Table- 2: Average satisfaction score of respondents regarding availed services of Indian Railways by the age group of the respondents

\begin{tabular}{|c|c|c|c|c|c|c|c|}
\hline \multirow{2}{*}{ Age(years) } & \multirow[b]{2}{*}{$\mathbf{N}$} & \multirow[b]{2}{*}{ Mean } & \multirow[b]{2}{*}{ S.D. } & \multicolumn{2}{|c|}{ 95\% Confidence Interval for Mean } & \multirow[t]{2}{*}{$\mathbf{F}$} & \multirow[t]{2}{*}{$\mathbf{p}$} \\
\hline & & & & LB & UB & & \\
\hline$<25$ & 31 & 3.29 & .938 & 2.95 & 3.63 & \multirow[t]{4}{*}{0.849} & \multirow[t]{4}{*}{$>0.05$} \\
\hline $25-44$ & 49 & 3.37 & .951 & 3.09 & 3.64 & & \\
\hline$>44$ & 6 & 3.83 & .753 & 3.04 & 4.62 & & \\
\hline Total & 86 & 3.37 & .934 & 3.17 & 3.57 & & \\
\hline
\end{tabular}

Source: - Field Survey

Table - 2 reveals age wise distribution of respondents on mean scores for their past experience of services availed from Indian Railways. The average experience of availed services of Indian Railways was highest (mean score 3.83) in the age group > 44 years followed by age group 25- 44 years (mean score 3.37) and $<25$ years (mean score 3.29). It can be observed that as there is an increase in age of respondents, mean score on experience also increases signifying that respondents of higher age groups had happier experience compared to younger respondents. However, $F$ ratio results show that differences in mean scores of experiences for availed services among different age groups were not statistically significant at $5 \%$ level of significance. Mean score on past experience of the services of Indian Railways, among all the age groups was above average.

Table-3: Average satisfaction score of respondents regarding availed services of Indian Railways by Gender

\begin{tabular}{|l|l|l|l|l|l|l|}
\hline Gender & N & Mean & S.D. & t & df. & p \\
\cline { 1 - 3 } & 43 & 3.30 & 1.103 & 0.691 & 84 & $>0.05$ \\
\cline { 1 - 3 } & 43 & 3.44 & .734 & & \\
\hline
\end{tabular}

Source: Field Survey.

Table -3 reveals gender-wise distribution of respondents on mean scores for their past experience of services availed from Indian Railways. It is inferred from the above table that both male and female had mean scores above average (3.00); but female respondents were more satisfied (mean score 3.44) compared to males (mean score 3.30). However, the result of t-test shows that difference in scores on experience of past visits, between males and females, was not statistically significant at $5 \%$ level of significance.

Table- 4: Distribution of Respondents by the opinion on changes in facilities of IR in comparison with their earlier visit to India

\begin{tabular}{|l|l|l|l|}
\hline \multirow{2}{*}{ Level of Changes } & Catering & Tourist Information System & $\begin{array}{l}\text { Timely Arrival \& Departure of } \\
\text { Trains }\end{array}$ \\
\cline { 2 - 4 } & Number $(\%)$ & Number (\%) & Number (\%) \\
\hline Significantly Worsened & $4(4.7)$ & $7(8.1)$ & $2(2.3)$ \\
\hline Worsened & $16(18.6)$ & $10(11.6)$ & $9(10.5)$ \\
\hline No Improvement & $38(44.2)$ & $31(36.0)$ & $28(32.6)$ \\
\hline Improvement & $27(31.4)$ & $26(30.2)$ & $36(41.9)$ \\
\hline Significant Improvement & $1(1.2)$ & $12(14.0)$ & $11(12.8)$ \\
\hline Total & $\mathbf{8 6}(\mathbf{1 0 0 . 0})$ & $\mathbf{8 6}(\mathbf{1 0 0 . 0})$ & $\mathbf{8 6}(\mathbf{1 0 0 . 0 )}$ \\
\hline
\end{tabular}

\section{Source: Field Survey.}

Table-4 shows the distribution of opinion of 86 respondents who had travelled by trains in their earlier visit(s), about changes felt in present visit from their past visit(s) on Catering, Tourist Information System and Timely arrival \& departure of trains. Out of 86 respondents $31.4 \%$ respondents in case of catering reported that they found an improvement; while only $1.2 \%$ reported that they felt significant improvement and $18.6 \%$ respondents found that it had worsened similarly. $4.7 \%$ said it had significantly worsened. The percentage of respondents who reported no improvement was $44.2 \%$. In case of foreign tourist information system, out of 86 respondents $30.2 \%$ respondents reported that they found an improvement; while only $14.0 \%$ said that they felt significant improvement while $11.6 \%$ respondents found that it had worsened and $8.1 \%$ said it had significantly worsened. The percentage of respondents who reported no improvement was 36.0. In case of timely arrival and departure of the trains; out of 86 respondents $41.9 \%$ respondents reported that they found an improvement while; only $12.8 \%$ said that they felt significant improvement while $10.5 \%$ respondents found that it had worsened and $5.3 \%$ said it had significantly worsened. The percentage of respondents who reported no improvement was 32.6 . 
Table- 5: Average score of satisfaction level of Respondents' attitude on changing facilities of IR in comparison with their earlier trip(s) by age groups

\begin{tabular}{|c|c|c|c|c|c|c|c|c|}
\hline \multirow{2}{*}{\multicolumn{2}{|c|}{$\begin{array}{l}\text { Perception of changing facilities } \\
\text { of IR by age }\end{array}$}} & \multirow[b]{2}{*}{$\mathbf{N}$} & \multirow[b]{2}{*}{ Mean } & \multirow[b]{2}{*}{ S. D. } & \multicolumn{2}{|c|}{$\begin{array}{l}95 \% \text { Confidence Interval for } \\
\text { Mean }\end{array}$} & \multirow[t]{2}{*}{$\mathbf{F}$} & \multirow[t]{2}{*}{$\mathbf{p}$} \\
\hline & & & & & LB & UB & & \\
\hline \multirow[t]{4}{*}{ Change in catering } & $<25$ & 31 & 3.06 & .727 & 2.80 & 3.33 & \multirow[t]{4}{*}{0.015} & \multirow[t]{4}{*}{$>0.05$} \\
\hline & $25-44$ & 49 & 3.06 & .922 & 2.80 & 3.33 & & \\
\hline & $>44$ & 6 & 3.00 & 1.095 & 1.85 & 4.15 & & \\
\hline & Total & 86 & 3.06 & .859 & 2.87 & & & \\
\hline \multirow{4}{*}{$\begin{array}{l}\text { Change in tourist } \\
\text { centre services }\end{array}$} & $<25$ & 31 & 3.52 & 1.262 & 3.05 & 3.98 & \multirow[t]{4}{*}{0.967} & \multirow[t]{4}{*}{$>0.05$} \\
\hline & $25-44$ & 49 & 3.16 & .965 & 2.89 & 3.44 & & \\
\hline & $>44$ & 6 & 3.33 & 1.366 & 1.90 & 4.77 & & \\
\hline & Total & 86 & 3.30 & 1.107 & 3.07 & 3.54 & & \\
\hline \multirow{4}{*}{$\begin{array}{l}\text { Change in timely } \\
\text { arrival departure of } \\
\text { trains }\end{array}$} & $<25$ & 31 & 3.87 & .957 & 3.52 & 4.22 & \multirow{4}{*}{\begin{tabular}{|l}
3.733 \\
Significant pairs \\
(1vs2)
\end{tabular}} & \multirow[t]{4}{*}{$<0.05$} \\
\hline & $25-44$ & 49 & 3.31 & .871 & 3.06 & 3.56 & & \\
\hline & $>44$ & 6 & 3.50 & .837 & 2.62 & 4.38 & & \\
\hline & Total & 86 & 3.52 & .930 & 3.32 & 3.72 & & \\
\hline
\end{tabular}

\section{Source: - Field Survey.}

Table -5 shows average score of improvement in facilities of catering, tourist center services and timely arrival and departure of trains on Indian Railways. Out of 86 respondents who have travelled by trains in their earlier visits to India; the mean score of perception on changes in catering facility for age group $<25$ and the age group 25 - 44 years of age groups were same (3.06); while mean score for the age group $>44$ years was little lower (3.00). The $\mathrm{F}$ ratio test points out that difference in mean scores by age groups are not statistically significant at 5\% level of significance. Mean score on changes in services of tourist centre from past was the highest (3.52) for the respondents below 25 years followed by a score of 3.33 for the age group above 44 years and a value of 3.16 for the same in the age group between 25 to 44 years. However, the test F ratio shows that difference in mean scores by age group were not statistically significant at $5 \%$ level of significance. Mean score on changes in timely arrival and departure of trains was highest (3.87) for the age group below 25 years; while it was 3.50 for above 44 years and 3.31 for age group of 25 to 44 years. However, the test F ratio shows that difference in mean scores by age group were not statistically significant at 5\% level of significance.

Table- 6: Distribution of Respondents on the basis of travelling purpose by Indian Railways

\begin{tabular}{|l|l|l|}
\hline Travelling Purpose & Number & Percentage \\
\hline Visiting Relatives and Friends & 12 & 4.8 \\
\hline Leisure, Recreation \& Holiday & 230 & 92.0 \\
\hline Others & 8 & 3.2 \\
\hline Total & $\mathbf{2 5 0}$ & $\mathbf{1 0 0 . 0}$ \\
\hline
\end{tabular}

Source: Field Survey.

Table-6 shows the distribution of respondents on the basis of travelling purpose of visiting in India. Out of total 250 respondents, majority of (92\%) foreign tourists travelling by trains in India with the purpose of Leisure, Recreations and Holiday in term of percentage as well as absolute number followed by (12) $4.8 \%$ respondents were travelling with purpose of visiting relatives and friends and only 8 (3.2\%) foreign tourists were travelling by trains with other purpose like medical care, religious, yoga etc.

Table - 7: Distribution of Respondent's as per influence/ sources of inspiration and age groups

\begin{tabular}{|c|c|c|c|c|}
\hline \multirow[t]{2}{*}{ Inspiration Sources } & \multicolumn{3}{|c|}{ Age } & \multirow[b]{2}{*}{ Total } \\
\hline & $<25$ & $25-44$ & $>44$ & \\
\hline Friends/Relatives/Past exp. & $51(68.0)$ & $90(59.2)$ & $12(52.2)$ & $153(61.2))$ \\
\hline Travel agents & $7(9.3)$ & $35(23.0)$ & $6(26.1)$ & $48(19.2)$ \\
\hline Media(Electronics \& Prints) & $17(22.7)$ & $27(17.8)$ & $5(21.7)$ & 49 (19.6) \\
\hline Total & 75 (100.0) & $152(100.0)$ & $23(100.0)$ & $250(100.0)$ \\
\hline
\end{tabular}

Source: Field Survey.

Table-7 represents the distribution of respondents according to inspiration sources and age groups. Out of total 250 respondents, $153(61.2 \%)$ foreign tourist were inspired by friends, relatives and their past experience 
of visiting to India; followed by $49(19.6 \%)$ respondents by Electronics and Prints media and 48(19.2\%) respondents through different travel agents. Out of total 75 respondents under the category of below 25 years; $68.0 \%$ foreign tourists were inspired by friends, relatives and past experience followed by $22.7 \%$ respondents through Electronics and Prints media and only 9.3\% foreign tourists were inspired by Travel Agents. Out of total 152 respondents in the age group between 25 to 44 years; $59.2 \%$ respondents were inspired by friends, relatives and their past experience followed by $23.0 \%$ foreign tourists through travel agents and only $17.8 \%$ respondents through Electronics and Prints media. Out of total 23 respondents in the age group of above 44 years, majority of this age group (52.2\% respondents) were influenced by their friends, relatives and past experience; followed by $26.1 \%$ respondents through travel agents and $21.7 \%$ foreign tourists through Electronics and Prints media. It is inferred from the above table that the respondent's inspiration sources (friends, relatives and past experience) effects on decreasing trend as the respondent's age increases; whereas this trend was reversed in the case of inspiration source of travel agents. But no trend was observed with Electronics and Prints media. It is also clear from $\chi^{2}$ test that the difference in source of inspiration among different age groups of respondents were not statistically significant at $5 \%$ level of significance and 4 degree of freedom

Table-8: Distribution of Respondents awareness FT Quotas by their age

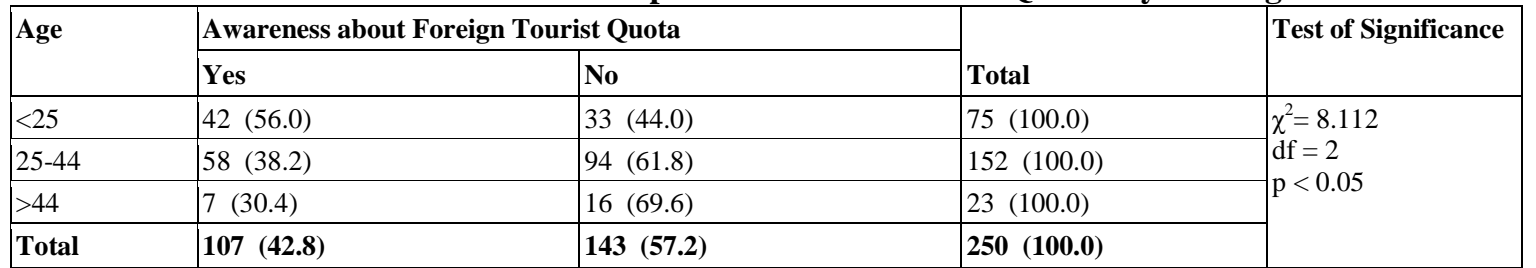

Source: Field Survey.

Table- 8 shows the age wise distribution of respondents by their awareness about Foreign Tourist (FT) Quota facility in trains on IR. Out of total respondents, $56.0 \%$ were aware in the age group of below twenty five years; $38.2 \%$ respondents were aware in the age group 25- 44 years and 30.4\% respondents in the age group of above 44 years were aware about the foreign quota facility. It can also be deduced from the above table that the highest percentage of respondents who availed foreign tourist quota belonged to the age group of 25 to 44 years. However, the result of $\chi^{2}$ test shows that the association between age and the use of foreign tourist quota was not statistically significant at $5 \%$ level of significance and 2 degrees of freedom.

Table -9: Distribution of Respondents by getting the reservation in FT Quota by age

\begin{tabular}{|c|c|c|c|c|}
\hline \multirow[t]{2}{*}{ Age } & \multicolumn{2}{|c|}{ Whether got Reservation in FT Quota } & \multirow[b]{2}{*}{ Total } & \multirow[t]{2}{*}{ Test of Significance } \\
\hline & Yes & No & & \\
\hline$<25$ & $24(32.0)$ & $51(68.0)$ & $75(100.0)$ & \multirow{4}{*}{$\begin{array}{l}\chi^{2}=1.259 \\
d f=2 \\
p>0.05\end{array}$} \\
\hline $25-44$ & $38(25.0)$ & $114(75.0)$ & $152(100.0)$ & \\
\hline$>44$ & $6(26.1)$ & $17(73.9)$ & $23(100.0)$ & \\
\hline Total & 68 (27.2) & $182(72.8)$ & $250(100.0)$ & \\
\hline
\end{tabular}

Source: Field Survey.

Table -9 shows the age wise distribution of respondents on the basis of getting reserved berths/seats in trains for present journey. Out of total respondents, $32.0 \%$ respondents in the age group of below twenty five years followed by $25 \%$ respondents in the age group $25-44$ years and $26.1 \%$ respondents in the age group of above 44 years could find reservation in foreign tourist quota. In the age group of above 44 years, more than $75.0 \%$ respondents were not availing FT quota facility to travel by trains. However, the association between age and the use of foreign tourist quota was not statistically significant at $5 \%$ level of significance and 2 degrees of freedom

Table 10: Distribution of Respondents' whether got reservation in FT Quota vs. Knowledge about FT Quota

\begin{tabular}{|c|c|c|c|c|}
\hline \multirow{2}{*}{$\begin{array}{l}\text { Knowledge about } \\
\text { FT Quota }\end{array}$} & \multicolumn{2}{|c|}{ Whether got Reservation in FT Quota } & \multirow[b]{2}{*}{ Total } & \multirow[t]{2}{*}{ Test of Significance } \\
\hline & Yes & No & & \\
\hline Yes & $60(56.1)$ & $47(43.9)$ & $107(100.0)$ & \multirow{3}{*}{$\begin{array}{l}\chi^{2}=78.763 \\
\text { df }=1 \\
p<0.05\end{array}$} \\
\hline No & $8(5.6)$ & $135(94.4)$ & $143(100.0)$ & \\
\hline Total & $68(27.2)$ & $182(72.8)$ & $250(100.0)$ & \\
\hline
\end{tabular}

Source: Field Survey.

Table -10 shows the distribution of respondent's knowledge about foreign tourist's quota and availing this quota for confirmed seats/berths in trains for tourists. Out of total 250 respondents, $27.2 \%$ foreign tourists 
were availing this quota and remaining $72.8 \%$ were travelling without this quota. The table reveals that the respondents who had knowledge about FT Quota; 56.1\% foreign tourists could get reservation through this quota; while $43.9 \%$ respondents could not. In case of those who were unaware of this FT Quota earlier and came to know about this quota at the time of reservation, only 5.6\% respondents got reservation in this quota. The $\chi^{2}$ test of significance shows that at 5\% significance level and 1 degree of freedom, the association between knowledge about FT Quota and getting confirmed berths/seats in this quota was statistically significant.

Table-11 shows out of total 250 respondents 6 (2.4) respondents have not responded. Out of answered 244 respondents, the level of satisfaction with the issue of safety and security in Trains as well as stations. The table reflects that in response to the issue related to safety in trains, $4.9 \%$ respondents were very much unsatisfied; while $16.8 \%$ respondents were unsatisfied. On the issue of Safety and security at stations, the percentage of unsatisfied foreign tourists $(26.2 \%)$ and the percentage of very much unsatisfied foreign tourists (8.6\%) were higher compared to their equivalents in case of Safety and security in trains. So, on this aspect too; the condition seems to be worsening at stations.

Table -11: Distribution of Respondents by level of satisfaction with Safety \& Security in Indian Railways

\begin{tabular}{|l|l|l|}
\hline \multirow{2}{*}{ Level of Satisfaction } & Safety \& Security & At Stations \\
\cline { 2 - 4 } & In Trains & $21(8.6)$ \\
\hline Very much unsatisfied & $12(4.9)$ & $64(26.2)$ \\
\hline Unsatisfied & $41(16.8)$ & $42(17.2)$ \\
\hline Average & $34(13.9)$ & $107(43.9)$ \\
\hline Satisfied & $132(54.1)$ & $10(4.1)$ \\
\hline Very Much Satisfied & $25(10.2)$ & $\mathbf{2 4 4}(\mathbf{1 0 0 . 0})$ \\
\hline Total Answered & $\mathbf{2 4 4}(\mathbf{1 0 0 . 0})$ & $6(2.4)$ \\
\hline No Answer & $6(2.4)$ & $\mathbf{2 5 0}$ \\
\hline Total & $\mathbf{2 5 0}$ & \\
\hline
\end{tabular}

Source: Field Survey.

Table-12: Average Score of Respondents' Satisfaction on Safety \& Security in Indian Railways by their age group

\begin{tabular}{|c|c|c|c|c|c|c|c|c|}
\hline \multicolumn{2}{|c|}{$\begin{array}{l}\text { Satisfaction with } \\
\text { Safety \& Security by age }\end{array}$} & \multirow[b]{2}{*}{$\mathrm{N}$} & \multirow[b]{2}{*}{ Mean } & \multirow[b]{2}{*}{ S.D. } & \multicolumn{2}{|c|}{$\begin{array}{l}\text { 95\% Confidence Interval for } \\
\text { Mean }\end{array}$} & \multirow[b]{2}{*}{ F } & \multirow[b]{2}{*}{$p$} \\
\hline & & & & & LB & UB & & \\
\hline \multirow[t]{4}{*}{ In Train } & $<25$ & 73 & 3.18 & 1.147 & 2.91 & 3.45 & \multirow{4}{*}{$\begin{array}{l}5.685 \\
\text { Significant pairs (1 } \\
\text { vs. } 2) \&(1 \text { vs. } 3)\end{array}$} & \multirow{4}{*}{$<0.05$} \\
\hline & $25-44$ & 148 & 3.56 & 1.005 & 3.40 & 3.72 & & \\
\hline & $>44$ & 23 & 3.91 & .668 & 3.62 & 4.20 & & \\
\hline & Total & 244 & 3.48 & 1.044 & 3.35 & 3.61 & & \\
\hline \multirow[t]{4}{*}{ At Stations } & $<25$ & 73 & 2.97 & 1.130 & 2.71 & 3.24 & \multirow{4}{*}{0.753} & \multirow{4}{*}{$>0.05$} \\
\hline & $25-44$ & 148 & 3.16 & 1.105 & 2.98 & 3.33 & & \\
\hline & $>44$ & 23 & 3.00 & .953 & 2.59 & 3.41 & & \\
\hline & Total & 244 & \begin{tabular}{|l|l|}
3.09 \\
\end{tabular} & \begin{tabular}{|l|l|}
1.098 \\
\end{tabular} & 2.95 & 3.22 & & \\
\hline
\end{tabular}

Source: Field Survey.

Table -12 shows the age wise average satisfaction score of Respondents on the issue of safety and security in trains and at stations. The mean satisfaction scores among the age groups <25years; $25-44$ years and $>44$ years were $3.18,3.56$ and 3.91 respectively. So we can notice that respondents in the higher age groups are feeling safer and compared to the respondents in lower age groups. As far as the issue of safety and security at stations is concerned, average satisfaction scores among the age groups <25years; 25-44 years and > 44 years were 2.97, 3.16 and 3.00 respectively. Among these three age groups, respondents in 25-44 year age group are most satisfied followed by the respondents in the group $>44$ years and $<25$ years respectively. So we can observe that relatively speaking young tourists feel most unsafe at stations as well as in trains. The table also reflects the differences in satisfaction levels of among all age groups on the issue of safety and security are statistically significant at $5 \%$ level of significance. But, Post Hoc test shows that pairs between below 25 and 25 to 44 age group and below 25 and more than 44 years age group are statistically significant. This means that there is association in age group and the level of satisfaction on safety \& security on specified age group. Whereas, in the case of safety and security at stations, $p$ value is greater than $5 \%$ significance level therefore difference found among different age groups with specified facilities are significantly similar.

Table- 13 represents the gender wise average satisfaction score of Respondents on the issue of safety 
and security in trains and at stations. On the issue of safety \& security issue in trains, mean satisfaction score of females was little lower (3.46) compared to that of males (3.50). Contrary to this, in case of safety and security at station, male respondents seems to be less satisfied as their average satisfaction score was 3.02 compared to a score of 3.14 for the females. The analysis shows that on the issue of satisfaction with safety and security in trains, there is no significant difference among males and females at the significance level of 5\%. However, on the issue of their level of satisfaction with safety and security at stations, they are significantly similar in their satisfaction levels at $5 \%$ level of significance.

Table-13: Average Score of Respondents' Satisfaction on Safety \& Security in Indian Railways by Gender

\begin{tabular}{|l|c|c|c|c|c|c|c|}
\hline \multicolumn{2}{|l|}{$\begin{array}{l}\text { Satisfaction with Safety \& } \\
\text { Security by Gender }\end{array}$} & $\mathbf{N}$ & Mean & S. D. & t & df & p \\
\hline \multirow{2}{*}{ In Trains } & Male & 113 & 3.50 & 0.992 & \multirow{2}{*}{.346} & \multirow{2}{*}{242} & \multirow{2}{*}{$>0.05$} \\
\cline { 2 - 9 } & Female & 131 & 3.46 & 1.090 & & \\
\hline \multirow{2}{*}{ At Stations } & Male & 112 & 3.02 & 1.115 & \multirow{2}{*}{-.893} & \multirow{2}{*}{242} & $>0.05$ \\
\cline { 2 - 6 } & Female & 132 & 3.14 & 1.085 & & \\
\hline
\end{tabular}

Source: Field Survey.

Table-14: Socio-economic distribution of respondents by the act of availing/not availing RTP

\begin{tabular}{|c|c|c|c|c|c|}
\hline \multirow[t]{5}{*}{$\mathbf{A}$} & \multirow[t]{2}{*}{ Gender } & \multicolumn{2}{|c|}{ Whether availing railway tour package } & \multirow[b]{2}{*}{ Total } & \multirow[t]{2}{*}{ Test of Significance } \\
\hline & & Yes & No & & \\
\hline & Male & $8(7.0)$ & $106(93.0)$ & $114(100.0)$ & \multirow{3}{*}{$\begin{array}{l}\chi^{2}=0.830 \\
d f=1 \\
p>0.05\end{array}$} \\
\hline & Female & $14(10.3)$ & $122(89.7)$ & $136(100.0)$ & \\
\hline & Total & $22(8.8)$ & $228(91.2)$ & 250 & \\
\hline \multirow[t]{4}{*}{$\mathbf{B}$} & \multicolumn{5}{|l|}{ Age } \\
\hline & $<25$ & $5(6.7)$ & $70(93.3)$ & $75(100.0)$ & \multirow{3}{*}{$\begin{array}{l}\chi^{2}=0.973 \\
d f=2 \\
p>0.05\end{array}$} \\
\hline & $25-44$ & $14(9.2)$ & $138(90.8)$ & $152(100.0)$ & \\
\hline & $>44$ & $3(13.0)$ & $20(87.0)$ & $23(100.0)$ & \\
\hline \multirow[t]{4}{*}{ C } & \multicolumn{5}{|l|}{ Educational Level } \\
\hline & Below UG & $4(8.7)$ & $42(91.3)$ & $46(100.0)$ & \multirow{3}{*}{$\begin{array}{l}\chi^{2}=.009 \\
d f=2 \\
p>0.05\end{array}$} \\
\hline & UG & $12(8.7)$ & $126(91.3)$ & $138(100.0)$ & \\
\hline & PG\& above & $6(9.1)$ & $60(90.9)$ & $66(100.0)$ & \\
\hline \multirow[t]{5}{*}{ D } & \multicolumn{5}{|l|}{ Occupation } \\
\hline & Business & $6(8.2)$ & $67(91.8)$ & $73(100.0)$ & \multirow{4}{*}{$\begin{array}{l}\chi^{2}=0.747 \\
\mathrm{df}=3 \\
\mathrm{p}>0.05\end{array}$} \\
\hline & \begin{tabular}{|l|} 
Govt. Service \\
\end{tabular} & $5(8.9)$ & $51(91.1)$ & $56(100.0)$ & \\
\hline & \begin{tabular}{|ll}
$\begin{array}{l}\text { Non Govt. } \\
\text { Professionals }\end{array}$ & $\&$ \\
\end{tabular} & $3(6.4)$ & 44 (93.6) & $47(100.0)$ & \\
\hline & Student & $8(10.8)$ & $66(89.2)$ & $74(100.0)$ & \\
\hline \multirow[t]{4}{*}{$\mathbf{E}$} & \multicolumn{5}{|l|}{ Annual Income } \\
\hline & $<15000$ & $8(10.0)$ & $72(90.0)$ & $80(100.0)$ & \multirow{3}{*}{$\begin{array}{l}\chi^{2}=1.239 \\
\mathrm{df}=2 \\
\mathrm{p}>0.05\end{array}$} \\
\hline & \begin{tabular}{|l|}
$15000-30000$ \\
\end{tabular} & $10(10.1)$ & $89(89.9)$ & $99(100.0)$ & \\
\hline & $\geq \mathbf{3 0 0 0 0}$ & $4(5.6)$ & 67 (94.4) & $71(100.0)$ & \\
\hline \multirow[t]{6}{*}{$\mathbf{F}$} & Continent & & & & \\
\hline & AMERICA & 3 (13.6) & $19(86.4)$ & $22(100.0)$ & \multirow{5}{*}{$\begin{array}{l}\chi^{2}=2.207 \\
\mathrm{df}=4 \\
p>0.05\end{array}$} \\
\hline & \begin{tabular}{|l|} 
EUROPE \\
\end{tabular} & $12(7.8)$ & $142(92.2)$ & $154(100.0)$ & \\
\hline & AFRICA & 0 & \begin{tabular}{|ll}
9 & $(100.0)$ \\
\end{tabular} & $9(100.0)$ & \\
\hline & AUSTRALIA & $1(10.0)$ & $9(90.0)$ & $10(100.0)$ & \\
\hline & ASIA & $6(10.9)$ & $49(89.1)$ & $55(100.0)$ & \\
\hline
\end{tabular}

Source: Field Survey; Note: Figures in parenthesis are percentages of the total in the respective rows.

The table-14 shows the socio economic distribution of respondents by the act of availing /not availing railway tour packages. Out of total 250 respondents, only 22 respondents $(8.8 \%)$ were availing Railway Tour packages. Gender wise analysis shows that out of these 22 respondents, 8 were males while 14 were females. On percentage basis too, a higher percentage of females (10.3\%) were using rail tour packages as compared to $7 \%$ male respondents. So, it seems that more number of females respondents avail Rail tour packages as compared to males. However, the difference is not statistically significant at one degree of freedom and $5 \%$ level of significance. Age wise analysis of the respondents who avail tour packages shows that in terms of absolute number, the majority of respondents belongs to the age category 25-44 years as 14 respondents in this class 
availed these packages while; 5 respondents in $<25$ year and 3 respondents in the class $>44$ availed them. On the basis of percentage, majority of the respondents (13.0\%); belongs to age group >44years; while only $9.2 \%$ respondents in the age category $25-44$ years and $6.7 \%$ respondents in the age category <25 years reported that they availed this facility. It seems that young users generally do not avail these packages. However the age wise difference in availing the tour packages was not found statistically significant at 2 degrees of freedom and $5 \%$ level of significance.

Education wise analysis shows that among the respondents who avail these packages, majority of respondents in absolute terms is under-graduate ( 12 respondents) followed by 6 respondents in Post Graduate \& above education class and 4 respondents in under graduate categories. We can see on the basis of percentage, in case of Post graduate \& above educated respondents $9.1 \%$ and in case of graduate respondents as well as in case of undergraduate respondents; equal respondents (8.7\%) availed these tour packages. Education wise differences among respondents in availing the tour packages were not found statistically significant at 2 degrees of freedom and $5 \%$ level of significance.

Occupation wise analysis shows that in terms of absolute number, majority of respondents who availed tour packages belonged to students category ( 8 respondents) followed by 6 businessmen, 5 Govt. Servants and 3 Non-govt. servants \& professionals. On the basis of percentage too, the majority belonged to students (10.8\%) followed by Govt. servants, $8.2 \%$ Non- Govt. Servants and 6.4\% Non Govt. servants \& professionals. So, students availed the tour packages more on the basis of number as well as percentage. However, Occupation wise differences among respondents in availing the tour packages were not found statistically significant at 3 degrees of freedom and 5\% level of significance.

Annual Income wise analysis of the respondents who avail tour packages shows that in terms of absolute number, the majority of respondents belongs to the income group 15000-30000 as 10 respondents in this group reported that they availed these packages while 8 respondents in the income group $<15000$ and 4 respondents in the class $>30000$ avail the packages. On the basis of percentage, the table reflects that majority of respondents (10.1\%) belongs to the Income group 15000-30000; while only almost an equal percentage (10\%) in $<15000$ income group and 5.6\% respondents in $>30000$ income group reported that they availed this facility. It seems that higher income group does not generally avail these packages. However, income wise difference in availing the tour packages were not found statistically significant at 2 degrees of freedom and $5 \%$ level of significance.

Continent wise analysis of the respondents shows that in terms of absolute numbers, majority of respondents who availed railway tour packages belonged to Europe. As Among those who availed these packages, 12 were Europeans, 6 were Asians, 3 were Americans, and 1 was Australian while none of them was an African. On percentage basis, we can see that majority belonged to Americans as $13.6 \%$ respondents among them availed these packages; while among Europeans $7.8 \%$ respondents, among Australians $10.0 \%$ respondents; among Asians, $10.9 \%$ respondents and among Africans no respondent availed Railway tour packages. So, with in its own category, in terms of absolute number, majority belonged to Europeans while in terms of percentage majority belonged to Americans. However, continent wise difference in availing the tour packages was not found statistically significant at 4 degrees of freedom and $5 \%$ level of significance.

Suggestions: Since very low percentage of foreign tourists is using the facilities like Rail tour packages, the special efforts are needed. To promote the tourism, some of the following suggestions are useful for further development in this sector.

1. Female tourists, elderly persons, students and under graduates are using more of tour packages. These categories of tourists generally avoid problems/hassles during the journey. So, special concessions for them may be given to increase in the tour packages.

2. Higher income group people do not generally avail Tour packages. This group is accustomed to luxuries and capable of paying more. So, provision of special facilities on extra cost may be helpful in attracting this segment of the tourists.

3. Since majority of tourists are Europeans or Americans, the provision of special facilities, like introducing European and American cuisines on the railway menu, appointment of coach attendants who are fluent in English languages are needed, Arrangement of stay in High class hotels and provision of transportation may be helpful in attracting more of these tourists.

4. Since majority of the foreign tourists come to India for the purpose of leisure, recreations and holidays. In this context, additional hospitality measures like playing movies reception at stations in local manner, provision of special waiting halls etc. results more enjoyable experience.

5. Though, it is good that most of tourists visit to India due to good word of mouth of their friends \& relatives, the role of Electronic or Print media and travel agents need to be increased. Running Tourism Promotion Campaigns on international channels may be a good idea. Further different promotional schemes for travel agents like sponsoring their trips to other countries on achieving a specified target may also improve the 
volume of tourists in India.

6. It was found that young tourists were aware more about foreign tourist quota and they were also availing more of this quota. Increased awareness may lead to increased use of a facility. So, efforts should be made that all the foreign tourists who visit India are aware about the facilities provided to them by Indian Railways. Approaching them at Airports at the time when they land up in India \& Providing them an information booklet containing the facilities given by Indian Railways, Helpline numbers and other related information may lead to an increased use of the facilities such as foreign quota.

7. Since majority of foreign tourists are females, a special quota may be fixed for female tourist. In case this remains unfilled, the seats may be transferred to other foreign tourists. Foreign tourists are also facing problem in getting reservations as per the results of study. Facilities like SMS reservations and Mobile reservations may be introduced specially for this segment.

8. Since most of the respondents belong to middle income group and are students, economy class tour packages may be launched for them.

9. Railway staff should be trained to deal with foreign tourists. Appreciation and incentives should be provided to those who do recommendable job in area of catering to requirements of foreign tourists.

10. Urgent attention and prompt actions are required towards cleanliness of trains and stations as well as cleanliness and hygiene of toilets. Promotion of civic sense is required here. Strict penalty and fine should be imposed on those who spread litters or create any kind of wastage. Trains and stations need to be washed on regular basis.

11. Safety and security is another issue. Increasing the number of security personnel in trains as well as at stations, installation of spy camera, entry and exit of persons after proper scanning and separate coaches for foreign tourists are some of the steps which may be applied in this regard.

12. Railway also needs to take immediate action to improve its catering and water management. The quality of Catering should be improved. Some packed continental instant foods should also be a part of the inventory. The trains which carry bulk of tourists should be identified and special food and water arrangements should be ensured.

13. Number of tourist centers should be increased and time to time training should be provided to its employees to improve service quality. Random assessment of performance should be done and punishment and incentives should be given according to the performance. A toll frees Helpline for foreign tourists may also be launched.

14. Seating arrangements on platforms as well as in waiting halls should be improved. Timely arrival \& departure of trains which carry bulk of foreign tourists should be ensured. Separate waiting rooms with all the necessary facilities and efficient staff should be provided for foreign tourists.

References:

[1]. Anderson, E. W., Fornell, C., \& Lehmann, D. R. (1994). Customer Satisfaction, Market Share and Profitability. Journal of Marketing, 58(3), 53-66.

[2]. Baker, D. A., \& Crompton J. L. (2000). Quality, Satisfaction and Behavioural Intentions. Annuals of Tourism Research, 27(3), 785804.

[3]. Barsky, J. D. (1992). Customer Satisfaction in the Hotel Industry: Meaning and Measurement. Hospitality Research Journal, 16(1), 51-73.

[4]. Bojonic, D. C., \& Rosen, L. D. (1994). "Measuring Service Quality in Restaurants: An Application of the SERVQUAL Instrument". Hospitality Research Journal, Vol. 18, No. 1, pp. 3-14

[5]. Buhalis, D. (2000), Marketing the competitive destination of the future, Tourism Management, 21(1), 97-116.

[6]. Chaudhary, M. (2000), India's image as a tourist destination - A perspective of foreign tourists, Tourism Management, 21, $293-297$.

[7]. Connell, J. (2006), Medical tourism: Sea, sun, sand and Surgery, Tourism Management, 27, 1093-1100.

[8]. Getz, D. (2008), Event tourism: Definition, evolution, and research, Tourism Management, 29, 403-428.

[9]. Gursoy, D., McCleary, K. W., \& Lepsito, L. R. (2003). Segmenting Dissatisfied Restaurant Customers Based on Their Complaining Response Styles. Journal of Food Service Business Research, 6(1), 25-44.

[10]. Halloway, J. C. (1998), The Business of Tourism, Addison Wesley, London.

[11]. Johnston, L. (2006), I Do Down-Under: Naturalizing Landscapes and Love through Wedding Tourism in New Zealand, ACME: An International E-Journal for Critical Geographies, 5(2), 191-208.

[12]. Karatepe, O. M. (2006). Customer Complaints and Organizational Responses: The Effects of Complainants' Perceptions of Justice on Satisfaction and Loyalty. International Journal of Hospitality Management, 25(1), 69-90.

[13]. Kozak, M., \& Rimmington, M. (2000). Tourist satisfaction with Mallorca, Spain, as an off- season holiday destination. Journal of Travel Research, 38, 260-269.

[14]. Kwortnik, R. J. (2008), Shipscape influence on the leisure Cruise experience, International Journal of Culture, Tourism and Hospitality Research, 2(4), 289-311.

[15]. Laws, E. (1997), Managing Packaged Tourism, International Thomson Business Press, London.

[16]. Michelle, S. (2009), A Research study to investigate the Medical Tourism Industry in South Africa, Ph.D. Thesis, NHTV Breda, University of Applied Sciences.

[17]. Middleton, V.T. and Clark, J. (2001), Marketing in travel and tourism, Butterworth-Heinneman, Oxford

[18]. Mill, R.C. and Morrison, A.M. (2002), The Tourism System, Kendall/Hunt Publishing, Dubuque, IA

[19]. Neal, J. D., \& Gursoy, D. (2008). A Multifaceted Analysis of Tourism Satisfaction. Journal of Travel Research, 47, 53-62.

[20]. Oppermann, M. (1999), Sex Tourism, Annals of Tourism Research, 26(2), 251-266. 
[21]. Page, S. and L. Lumsdon (eds.) (2004) Tourism and transport: Issues and agenda for the new millennium, Elsevier, Boston.

[22]. Philip, G., \& Hazlett, S. A. (1996). The Measurement of Service Quality: A New P-C.P. Attributes Model. International Journal of Quality and Reliability Management, 14(3), 260-288.

[23]. Reisinger, Y., \& Turner, L. W. (2003).Cross-Cultural Behaviour in Tourism: Concepts and Analysis (pp.1-341).Oxford: Butterworth-Heinemann.

[24]. Saleh, F., \& Ryan C., (1992). "Client Perceptions of Hotels”. Tourism Management (June), Vol. 13, No.2, Pp. 163-168.

[25]. Sin, H. L. (2009), Volunteer tourism -involve Me and I will learn“, Annals of Tourism Research, 36(3), 480-501.

[26]. Stoneman, P., Wong, V. and Turner, W. (1995), The Green Challenge - The market for eco-friendly products, Warwick Business School, 1(1)

[27]. Trauer, B. (2006), Conceptualizing special interest tourism - frameworks for analysis, Tourism Management, 27, 183-200

[28]. Weber, K. (2001), Outdoor adventure tourism: A review of research approaches, Annals of Tourism Research, 28(2), 360-377.

[29]. Wheeler, M. (1995), Tourism marketing ethics: an introduction, International Marketing Review, 12(4), 38-49. 